\title{
Operational Practices of Lean Manufacturing: Potentiating Environmental Improvements
}

\author{
Marcos José Alves Pinto Junior(iD, Juliana Veiga Mendes (iD) \\ Federal University of São Carlos - Campus Sorocaba (Braziil) \\ marcosalvesin@yahoo.com.br,juveiga@ufscar.br
}

Received: February 2017

Accepted: September 2017

\section{Abstract:}

Purpose: The objective of this paper is to investigate how environmental improvements can be achieved through operational practices of Lean Manufacturing.

Design/methodology/approach: A literature review was conducted to analyze the relationship between operational practices of Lean and reduction of environmental impact in organizational contexts. Verified theoretically, this relationship was observed in a company of the electronics industry, through an exploratory research which contemplated a mixed approach. The adopted research method consisted of a single case study, by providing greater depth and detail of the study. Utilized a research protocol, validated pilot test. The instruments for data collection were semi-structured interviews, direct observation and document analysis. The information was examined qualitatively considering the technique for content analysis.

Findings: As a result of the study, it was found that there is evidence for the existence of relationship between the practices of Lean, for example, Kaizen, PDCA (plan, do, check, act), Ishikawa Diagram, Poka-Yoke, and Standardized Work, with the reduction of environmental impacts of an organization. This reduction was observed after application of these practices that resulted in the reduction of energy consumption and water consumption. These results were accounted for financially, contributing to a reduction of annual costs by about US $\$ 17,900$. 
Originality/value: The study presents in detail, the application of operational practices of Lean Manufacturing, with an effective view to reducing the environmental impact and cost reduction. The literature review, a detailed description of the application process and financial results are important information that contributes to the scientific studies that address traditional operating practices and the search for better environmental performance.

Keywords: lean manufacturing, operational practices, environmental performance

\section{Introduction}

Environmental problems have been part of the daily life of organizations since they are increasingly being pressured by society and the government to minimize damages to the environment. In this context, the manufacturing industry was seen as the main source of many environmental and social problems (Baldwin, Allen, Winder, \& Ridgway, 2005), and it focuses on various environmental regulations, such as the National Policy on Solid Waste, Waste Electrical and Electronic Equipment, Restriction of Hazardous Substances, e-Waste Association of South Africa, and others.

Organizational culture helps determine how much a company values for environmental preservation (Mollenkopf, Stolze, Tate, \& Ueltschy, 2010). Practices or techniques integrated to the organizational system for environmental protection can be determinant for reducing the environmental impact (Sarkis, 2003; Bergmiller \& Mccright, 2009).

In this way, it becomes necessary to incorporate techniques or practices in the organizational system to reduce the environmental impact. These techniques or practices can help control the use of resources during the production process or also in product design (Andriankaja, Vallet, Le Duigou, \& Eynard, 2015; Houe \& Grabot, 2009; Zhang, Zhan, Liu, Zhang, \& Li, 2011; Chiang \& Roy, 2012; Fiksel, 2009). Baumann, Boons and Bragd (2002) and Dangelico and Pontrandolfo (2010), seek to integrate environmental aspects into products to minimize the risks of emissions emitted during production, consumption and disposal.

The use of Lean practices can contribute to the perpetuation of a stable or improved process in terms of waste (Womack, Jones \& Roos, 1990; Ohno, 1997; Shingo, 1996; McLachlin, 1997; Shah \& Ward, 2003, 2007; Li, Rao, Ragu-Nathan, \& Ragu-Nathan, 2005; Browning \& Heath, 2009). As an organization uses Lean practices, it is expected to reduce waste from its production activities through environmental management practices, minimizing costs (Womack et al., 1990; Ohno, 1997; Shingo, 1996). Lean production practices and environmental management are distinct and have a different impact on business 
performance results (Kleindorfer, Singhal, Van Wassenhove, 2005; Yang, Hong, Modi, 2011; Paumgartten, 2003; Maxwell, Briscoe, Schenk \& Rothenberg, 1998; Martinez, Vazquez-Brust, Peattie \& Zokaei, 2012; Zhao, Huo, Flynn \& Yeung, 2008), but may be complementary when treated for the disposal of waste or waste.

A Lean Manufacturing company typically uses some alternatives as an approach that seeks to better organize and manage a company's relationships with its customers, supply chain, product development, and production operations, whereby it is possible to increase productivity by efficiently utilizing the resources (Womack \& Jones, 1998; Azevedo, Carvalho, Duarte \& Cruz-Machado, 2012; Carvalho, Azevedo, Cruz-Machado, 2010; Dües, Tan \& Lim, 2013; Espadinha-Cruz, Grilo, Puga-Leal \& Cruz-Machado, 2011; Govindan, Azevedo, Carvalho \& Cruz-Machado, 2015; Hajmohammad, Vachon, Klassen \& Gavronski, 2013; Parveen, Kumar, Narasimha-Rao, 2011; Simpson \& Power, 2005). The use of resources efficiently means not to waste it in all spheres, including natural resources (Womack \& Jones, 1998; Azevedo et al., 2012; Carvalho et al., 2010; Dües et al., 2013).

The results of the work Yang et al. (2011), Bandehnezhad, Zailani and Fernando (2012) evidence that Lean Manufacturing improves environmental management practices. Environmental management practices are programs to improve the environmental performance of processes and products (Matos \& Hall, 2007; Miettinem \& Hamalainen, 1997; Montabon, Sroufe \& Narasimhan, 2007; Sroufe, 2003; Bandehnezhad et al., 2012). The knowledge used to reduce internal waste through Lean Manufacturing is useful in the management of environmental waste (Yang et al., 2011).

The overlapping of Lean paradigms and environmental management techniques are standard with respect to waste reduction and environmental impact technologies (Chiang \& Roy, 2012; Garza-Reyes, Winck-Jacques, Lim, Kumar \& Rocha-Lona, 2014; Dües et al., 2013; Garza-Reyes, 2015; Larson \& Greenwood, 2004; Johansson \& Sundin, 2014; Wiengarten, Fynes \& Onofrei, 2013). Lean encompasses a wide variety of managerial practices about the production process. These practices should work synergistically to create a high quality system that manufactures products at the pace the customer wants, without waste (Shah \& Ward, 2003; Piercy \& Rich, 2015; Wiengarten et al., 2013; Salleh, Kasolang \& Jaffar, 2012; Belekoukias, Garza-Reyes \& Kumar, 2014).

Electronic waste is chemically different from other municipal or industrial waste and contains several hazardous materials, such as lead, mercury, polybrominated biphenyl and diphenyl (Araújo, Magrini, Mahler \& Bilitewski, 2012). Its disposal, short lifecycle and programmed obsolescence are also problems that must be addressed. It is the fastest growing waste stream in the world (Orlins \& Guan, 2015). For this reason, the electronics industry will be the research environment of this study. 
Thus, considering the impact caused by e-waste and the diffusion of Lean practices in manufacturing environments, it is questioned, in this work, how operational practices of this approach can contribute to the environment? A review of the literature presented in the topic on Lean and environmental aspects, evidence that the subject is well studied, but no study was found that would illustrate operationally how this can occur. The Lean aims at financial improvement, focusing on productivity and quality through various operational practices.

From this perspective, this research seeks to investigate in detail how environmental improvements are achieved through Lean Manufacturing operating practices in the electronics industry.

\section{Lean Manufacturing and Environmental Aspects}

Lean Manufacturing focuses on operations, processes, technology, quality, capacity, physical arrangement, supply chains, inventory and resource planning strategies. Lean Manufacturing groups all this together creating efficient processes (Ohno, 1997; Shingo, 1996; Ritzman \& Krajewski, 2004). It can be defined as a set of practices focused on the reduction of waste and non-value-added activities from manufacturing operations of a company (Womack et al., 1990; McLachlin, 1997; Shah \& Ward, 2003, 2007; Li et al., 2005; Browning \& Heath, 2009).

Considering the reduction of waste that is inherent to Lean, many studies have tried to present the relationship between Lean and environmental practices. Lean's adoption of these practices can reduce environmental costs and reduce environmental impact by using the least possible resource of nature. Table 1 presents areas of Lean relationship exploration and environmental practices in the literature.

Table 1 shows that the relationship between Lean and environmental practices is explored more strongly in supply chains and manufacturing industries. Industries have been seeking to adopt environmental practices in their Lean production environment. The adoption of environmental practices involves not only the development of more sustainable products but also using more sustainable processes to produce these products (Pusavec, Krajnik \& Kopac, 2010; Chiarini, 2014; Carvalho, Duarte \& Cruz-Machado, 2011). To achieve these results, Lean Manufacturing makes use of various tools designed to be used in operational and routine activities that are aligned with the purpose of the Lean. Some of the Lean practices and their definition are presented in the literature in Table 2. 


\begin{tabular}{|c|c|}
\hline Literature & Areas of exploration \\
\hline Atkinson (1994) & Manufacturing \\
\hline Cagno, Trucco \& Tardini (2005) & Manufacturing \\
\hline Campos \& Vazquez-Brust (2016) & Supply chain \\
\hline $\begin{array}{l}\text { Chandrakumar, Gowrynathan, Kulatunga } \\
\text { \& Sanjeevan (2016) }\end{array}$ & Transport Terminals \\
\hline Dhingra, Das \& Kress (2012) & Manufacturing \\
\hline Dhingra, Kress \& Upreti (2014) & Theoretical \\
\hline Dües et al. (2013) & Supply chain \\
\hline Faulkner \& Badurdeen (2014) & Manufacturing \\
\hline Fercoq, Lamouri \& Carbone (2016) & Manufacturing \\
\hline Florida (1996) & Manufacturing and Supply Chain \\
\hline Galeazzo, Furlan \& Vinelli (2014) & Manufacturing \\
\hline Garza-Reyes (2015) & Theoretical \\
\hline Govindan et al. (2015) & Supply chain \\
\hline Hajmohammad et al. (2013) & Supply chain \\
\hline Jabbour, Jabbour, Freitas \& Teixeira (2013) & Automotive industry \\
\hline Johansson \& Sudin (2014) & Theoretical \\
\hline King \& Lenox (2001) & Manufacturing \\
\hline Miller, Pawloski \& Standridge (2010) & Production of small furniture \\
\hline Pampanelli, Found \& Bernardes (2014) & Manufacturing \\
\hline Parveen et al. (2011) & Manufacturing and Supply Chain \\
\hline Piercy \& Rich (2015) & Multiple cases \\
\hline Pojasek (2008) & Theoretical \\
\hline Sagnak \& Kazancoglu (2016) & Multiple cases \\
\hline Salleh et al. (2012) & Automotive industry \\
\hline Simpson \& Power (2005) & Supply chain \\
\hline Thank, Govindan \& Thakkar (2016) & Small Business \\
\hline Ugarte, Golden, Dooley (2016) & Supply chain \\
\hline Varrier, Rose \& Caillaud (2016) & Theoretical \\
\hline Zokaei, Lovins, Wood \& Hines (2013) & Multiple cases \\
\hline Zwetsloot (1995) & Theoretical \\
\hline
\end{tabular}

Table 1. Areas of exploitation between Lean and environmental practices in the literature 


\begin{tabular}{|c|c|c|}
\hline Lean tools & Definition & Literature \\
\hline $5 S$ & $\begin{array}{l}\text { Organizational and cleaning methodology that reduces resources } \\
\text { and costs }\end{array}$ & Kobayashi (2005) \\
\hline Value Stream Map & $\begin{array}{l}\text { Mapping of the flow of materials and information needed to } \\
\text { transform raw material into finished product }\end{array}$ & Rother \& Shook (2003) \\
\hline Standard Work & $\begin{array}{l}\text { Standard work reduces waste, reduces workload and risks of } \\
\text { accidents, and increases worker productivity and satisfaction }\end{array}$ & $\begin{array}{l}\text { Whithmore (2008); Kishida, } \\
\text { Silva \& Guerra (2006) }\end{array}$ \\
\hline Kaizen - PDCA & $\begin{array}{l}\text { Methodology that reduces costs and increases productivity, and the } \\
\text { PDCA cycle can be your form of management }\end{array}$ & Imai (1986) \\
\hline Ishikawa Diagram & $\begin{array}{l}\text { It is a graphical representation that illustrates relationships between } \\
\text { a specific result and its causes }\end{array}$ & $\begin{array}{l}\text { American Society for Quality; } \\
\text { Ishikawa \& Loftus (1990) }\end{array}$ \\
\hline $\begin{array}{l}\text { Cellular } \\
\text { Arrangement }\end{array}$ & $\begin{array}{l}\text { In the physical arrangement of a cell, operations and processes are } \\
\text { grouped according to the sequence of production of a given } \\
\text { product family, taking into account the most efficient way to use the } \\
\text { resources }\end{array}$ & Black (1998) \\
\hline Golf Score & $\begin{array}{l}\text { Checklist for ergonomics, where ergonomic problems are scored as } \\
\text { a way of evaluating the job }\end{array}$ & $\begin{array}{l}\text { Definition given by the } \\
\text { company of the researched case }\end{array}$ \\
\hline Water spider & $\begin{array}{l}\text { Rapid and efficient movement to collect and deliver materials or } \\
\text { supplies to the primary members of a cellular flow }\end{array}$ & Womack \& Jones (1998) \\
\hline Card material & $\begin{array}{l}\text { Card that accompanies the material, making it possible to pull the } \\
\text { items from the production line from the final demand of a product, } \\
\text { providing information about the product or item in question }\end{array}$ & Shingo (1996) \\
\hline SMED & System to reduce the time of machine setup & Womack \& Jones (1998) \\
\hline $\begin{array}{l}\text { Autonomous } \\
\text { Inspection }\end{array}$ & $\begin{array}{l}\text { People or groups that aim to improve the performance of the } \\
\text { equipment through communication and eliminate possible failures } \\
\text { and problems with the equipment in their inspection }\end{array}$ & Swanson (2001) \\
\hline Poka-yoke & $\begin{array}{l}\text { Mechanism that reduces the production of defective parts, } \\
\text { regardless of the operator's attention }\end{array}$ & Shingo (1988) \\
\hline $\begin{array}{l}\text { Total productive } \\
\text { maintenance }\end{array}$ & $\begin{array}{l}\text { Maintenance performed by the operator or in small groups in a } \\
\text { minimum of time and in a preventive way }\end{array}$ & Nakajima (1988) \\
\hline Heijunka & $\begin{array}{l}\text { Control of variability of the sequence of jobs allowing greater } \\
\text { utilization of the capacity employed }\end{array}$ & $\begin{array}{l}\text { Hüttmeir, Treville, Ackere, } \\
\text { Monnier \& Prenninger (2009) }\end{array}$ \\
\hline
\end{tabular}

Table 2. Definition of Lean Manufacturing operational practices

Fiksel (2009) presents some organizational characterizations when environmental practices are adopted by a Lean company:

- Modification of traditional Lean tools, such as MFV, adding environmental aspects;

- Application of Lean tools for environmental, health and safety processes, such as wastewater treatment to increase efficiency;

- Integration of traditional pollution prevention techniques with Lean tools for the environment, providing a systematic way to find opportunities.

EPA (2006) presents how Lean Manufacturing tools can be applied to environmental waste management. It establishes guidelines for the use of lean production tools to improve the flow of materials in the main 
streams that support the manufacturing process and which in turn can affect the environment, such as energy, chemicals and other types of waste. With this concern with dangerous products, the next chapter is necessary to contextualize the situation of the case studied, Poka-yoke, and Standardized Work.

A Lean company targets sustainability initiatives through operational practices. Thus, Lean approaches at all organizational levels activities related to economic sustainability and environmental sustainability (Pampanelli et al., 2014).

\section{Methods}

This is an exploratory research to provide greater familiarity with the problem, to make it more explicit or to construct hypotheses. The steps of the methodological procedure for conducting this research are presented in Figure 1.

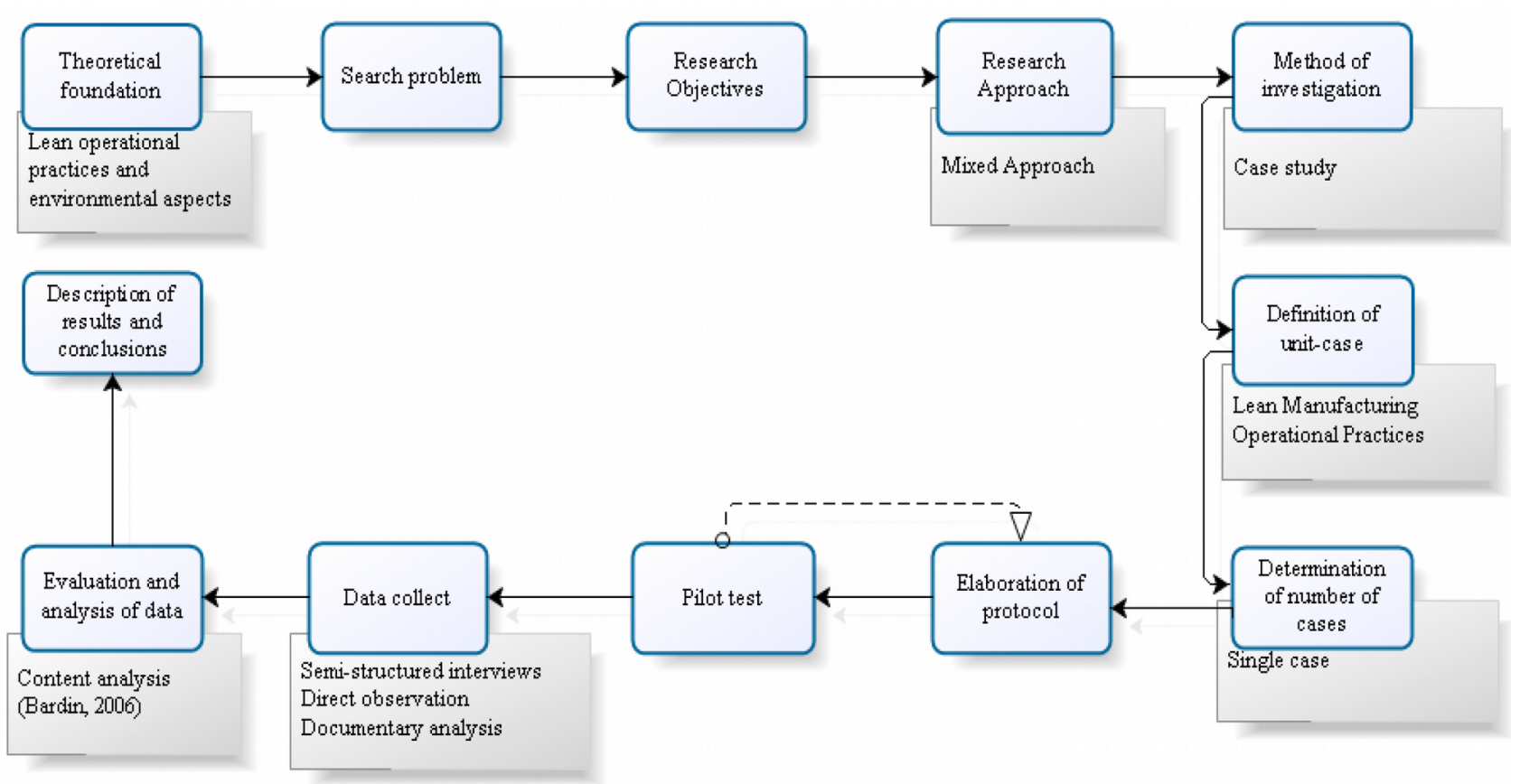

Figure 1. Methodological procedures

The approach used is mixed, since it seeks to qualify and measure the events studied for data analysis, as well as its emphasis on the acquisition of comprehension and depth of data (Godoy, 1995; Hooley, Piercy \& Nicoulaud, 2011). 
The method used is the single case study, which seeks to deepen the unit-case researched. Voss, Tsikriktsis and Frohlich (2002) and Yin (2010) affirm that the case study has a greater wealth in data collection when it is intended to exhaustively research one or a few objects. Eisenhardt (1989) and Yin (2001) affirm that the Case Study is a research strategy that focuses on understanding the dynamics present within individual configurations and is supported by a theoretical framework that guides the questions and propositions of the study, gathering information obtained through several techniques of data collection and evidence (Martins, 2008). In this study propositions are:

- How Lean Manufacturing operating practices can bring about environmental improvements?;

- Which Lean Manufacturing operating practices can contribute positively to the environment?.

The unit-case understood are operational practices of Lean Manufacturing, seeking to understand their relationship with the environment and how these practices can bring reduced environmental impact within the electronics industry. The researched environment is the electronics sector because it presents constant development and participation in daily human life. Also, it presents many problems through the waste generated by the industry, justifying the dynamics and the choice of the research.

As planning for the research, a protocol was developed to conduct the case study, available in Appendix A. The procedures for data collection are presented in Figure 2.

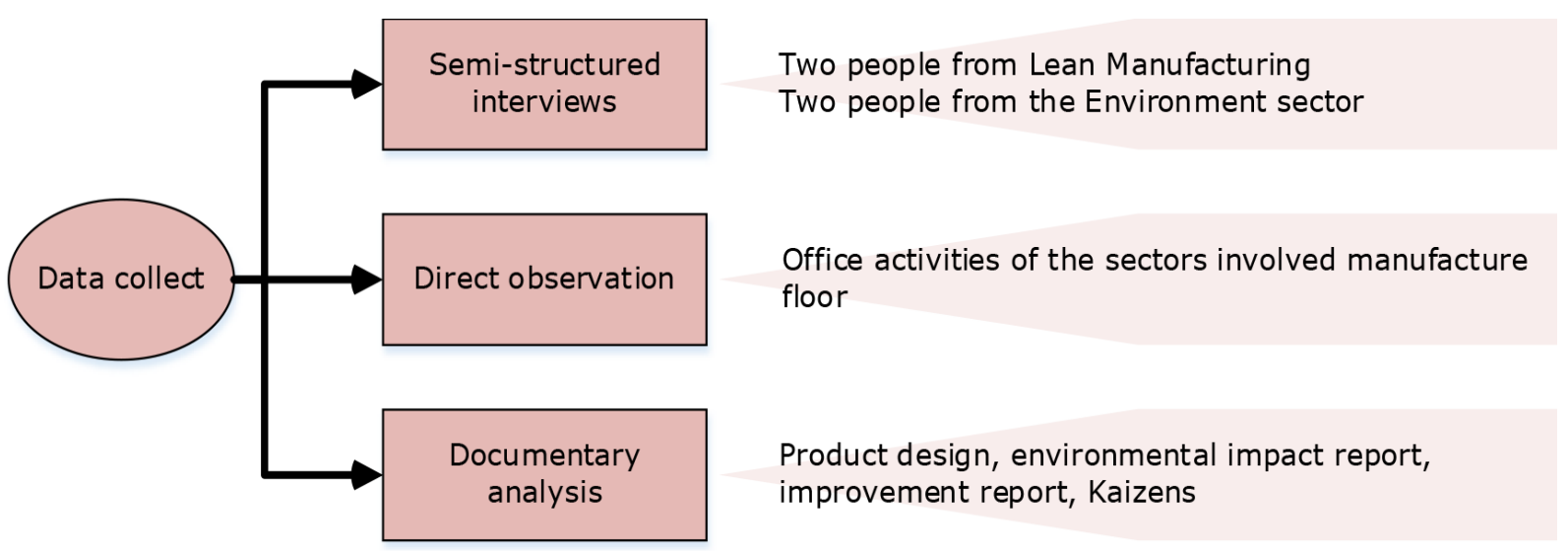

Figure 2. Data collection procedures

To analyze the data, the content analysis technique was used. This method can be defined as a set of methodological tools, continually improving, which lends itself to analyzing different sources of content, verbal or non-verbal (Freitas, Cunha Jr. \& Moscarola, 1997). Content analysis has gained popularity since 
Bardin (1977), which emphasizes the importance of the rigorous use of content analysis, the need to overcome uncertainties and find out what is being questioned.

The semi-structured script (Appendix B) contains questions to be observed in the company environment as well as questions for the purpose of content analysis. These questions are numbered 9-14. Some of these questions are specific to be answered by the Lean industry as well as others by the environmental sector. The content analysis process is depicted in Figure 3. The content analysis is detailed in Appendix C. Questions are required for checking the defined categories and subcategories.

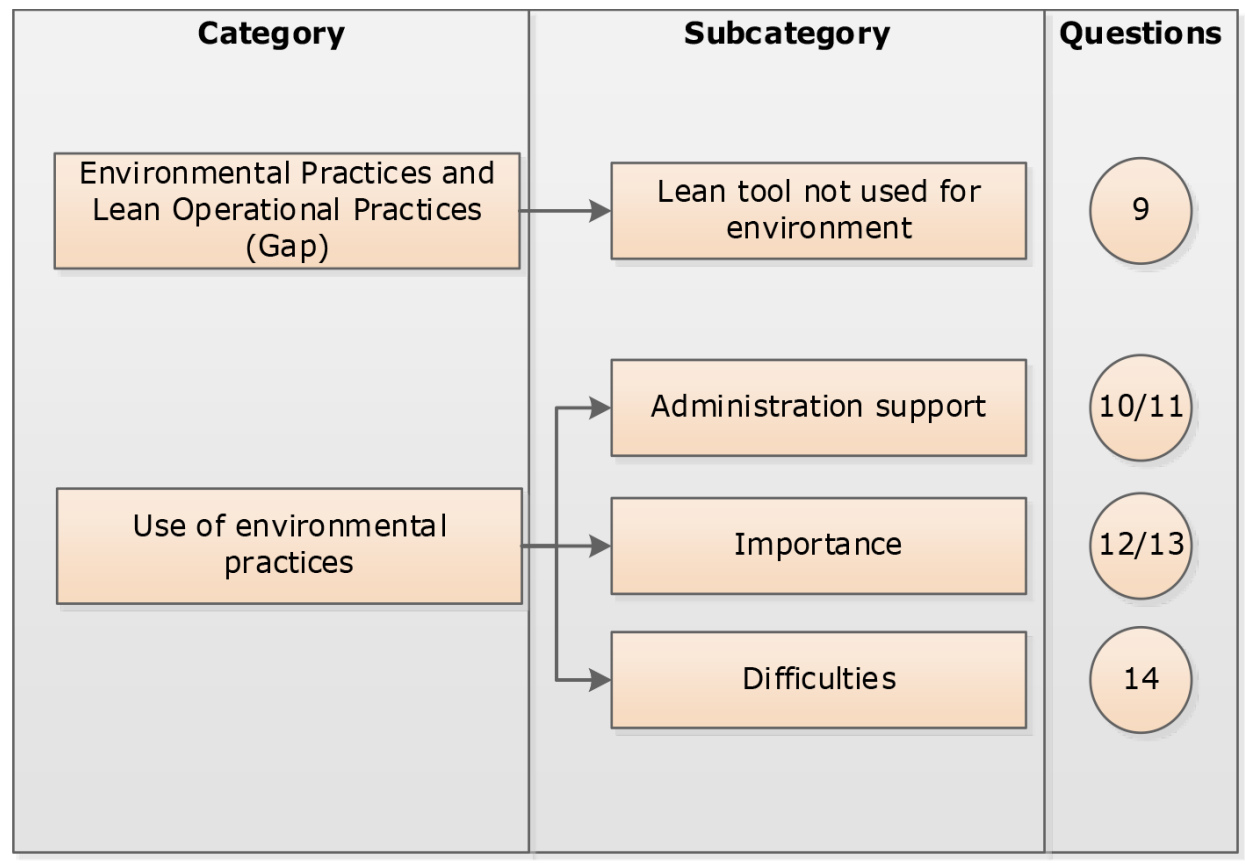

Figure 3. Categorization process for content analysis

\section{Description of the Case Study}

Keeping the company's name confidential, it is called Alpha. It is a manufacturer of computers, printers, credit card machines, servers, base station, Global Positioning System - GPS, tablets and electronic circuit boards.

Alpha helps customers design, build, distribute and repair electronic products through a network of facilities in thirty countries on four continents, with more than two hundred thousand employees. The unit surveyed is located in Latin America.

Electronic waste is a great challenge to be solved with society, organizations, and government. These problems are related to many aspects, such as investments in physical structure for consumers to return 
waste; Changes in business processes; Changes in consumer behavior related to disposal and consumption of electronic waste; Greater government involvement; The creation of incentives in terms of government taxes for companies, and the existence of information technology and systems necessary to control the flow of electronic waste, among others (Bouzon, Govindan \& Rodriguez, 2015, Santos \& Marins, 2015).

Global mobile penetration reached $91 \%$ in the third quarter of 2012, and mobile subscriptions totaled about 6.4 billion. The number of people using mobile devices will exceed 4 billion by 2018 (Ericsson, 2012). According to Chan and Wong (2013), electronic waste has been increasing rapidly worldwide, and it is estimated that 20 to 50,000,000 tons of it were produced annually around the world, where $70 \%$ enters China due to low recycling costs.

The management for Lean Manufacturing is divided into Manufacturing (operations), Services and Supply Chain/Office, being carried out by different people. Alpha uses some Lean operating practices. These practices and the form they use are outlined in Table 3.

\begin{tabular}{|c|c|}
\hline Lean tools & Utilization \\
\hline $5 \mathrm{~S}$ & It consists of a systematic identification and elimination of waste using organization and cleaning \\
\hline Value Stream Map & $\begin{array}{l}\text { Tool that consists of a standard way of identifying the entire organizational process in your value } \\
\text { stream }\end{array}$ \\
\hline Standard Work & $\begin{array}{l}\text { Method for standardization of operational work, taking into account production time and lead } \\
\text { time of delivery }\end{array}$ \\
\hline Kaizen - PDCA & $\begin{array}{l}\text { The structure of Kaizen events, identifying, analyzing and disseminating projects for short-term } \\
\text { results. It is performed based on management by PDCA }\end{array}$ \\
\hline Ishikawa Diagram & Graphic structure to identify environmental causes related to proposed problems \\
\hline Cellular Arrangement & Methodology of waste reduction by cellular layout using the Lean concepts of production \\
\hline Golf Score & $\begin{array}{l}\text { Used for ergonomics, where the level of movement of the worker is punctuated. Those with } \\
\text { higher scores are prone to ergonomic risks }\end{array}$ \\
\hline Water spider & $\begin{array}{l}\text { Management of logistic work to reduce material in production lines. Focus on controlling and } \\
\text { reducing inventory in the process }\end{array}$ \\
\hline Card material & Card where it contains product data to be processed trought the process quickly and accurately \\
\hline SMED & Method to reduce setup activities in product exchanges, tools, machines and operators \\
\hline $\begin{array}{l}\text { Autonomous } \\
\text { Inspection }\end{array}$ & Specific checks performed by process operators \\
\hline Poka-yoke & Error-proof device for non-occurrence of defects in the process, working in a preventive way \\
\hline $\begin{array}{l}\text { Total productive } \\
\text { maintenance }\end{array}$ & $\begin{array}{l}\text { Maintenance management of machines and equipment where the focus is the way people deal } \\
\text { with such problems }\end{array}$ \\
\hline Heijunka & Method for leveling production through optimal planning and sequence \\
\hline
\end{tabular}

Table 3. Use of Lean tools in Alpha 
Lean operational practices support all of the company's Lean philosophy to be effective. An overview of the Alpha Lean system can be seen in Figure 4. This system is implemented in all of its units.

The company internally has a database or Sharepoint containing the best practices performed by the entire company in its different units scattered in thirty-two countries. From time to time, they receive a visit from an outside consultant to carry out Kaizen improvements by specialists in the field.

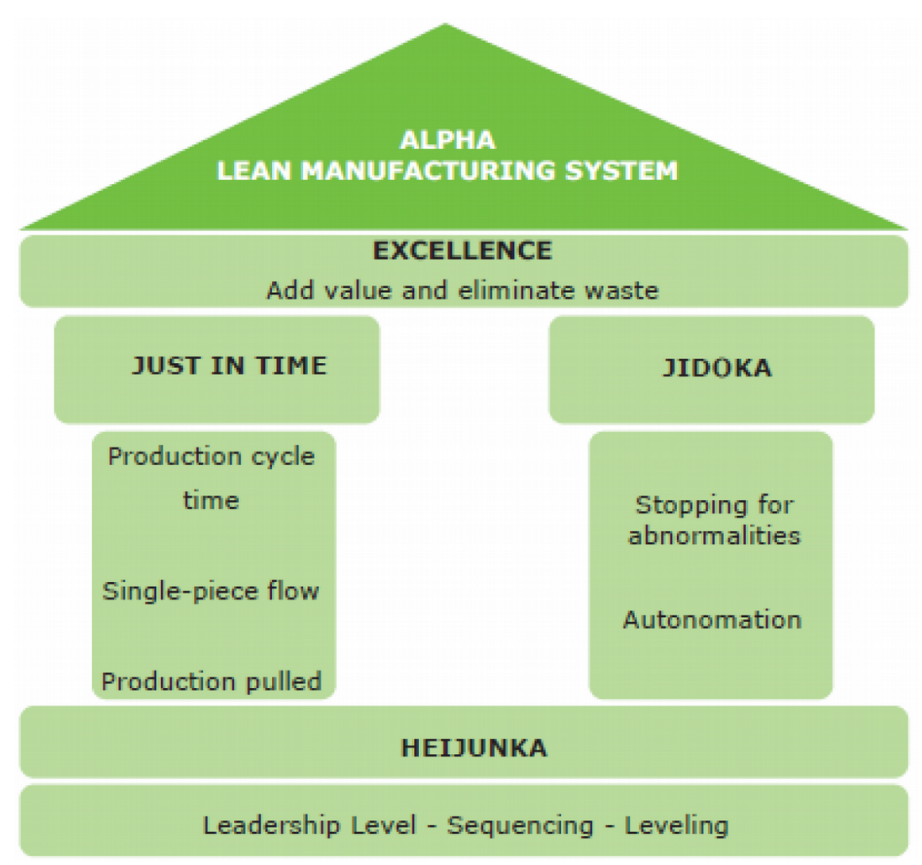

Figure 4. Alpha Lean Manufacturing System 


\section{Results: Lean Operational Practices for Environmental Improvements}

Seeking to reduce environmental waste by $15 \%$, Alpha defined two projects intended to reduce energy and water consumption. The projects are managed by a group responsible for Kaizen, which uses a PDCA methodology for management, illustrated in Figure 5.

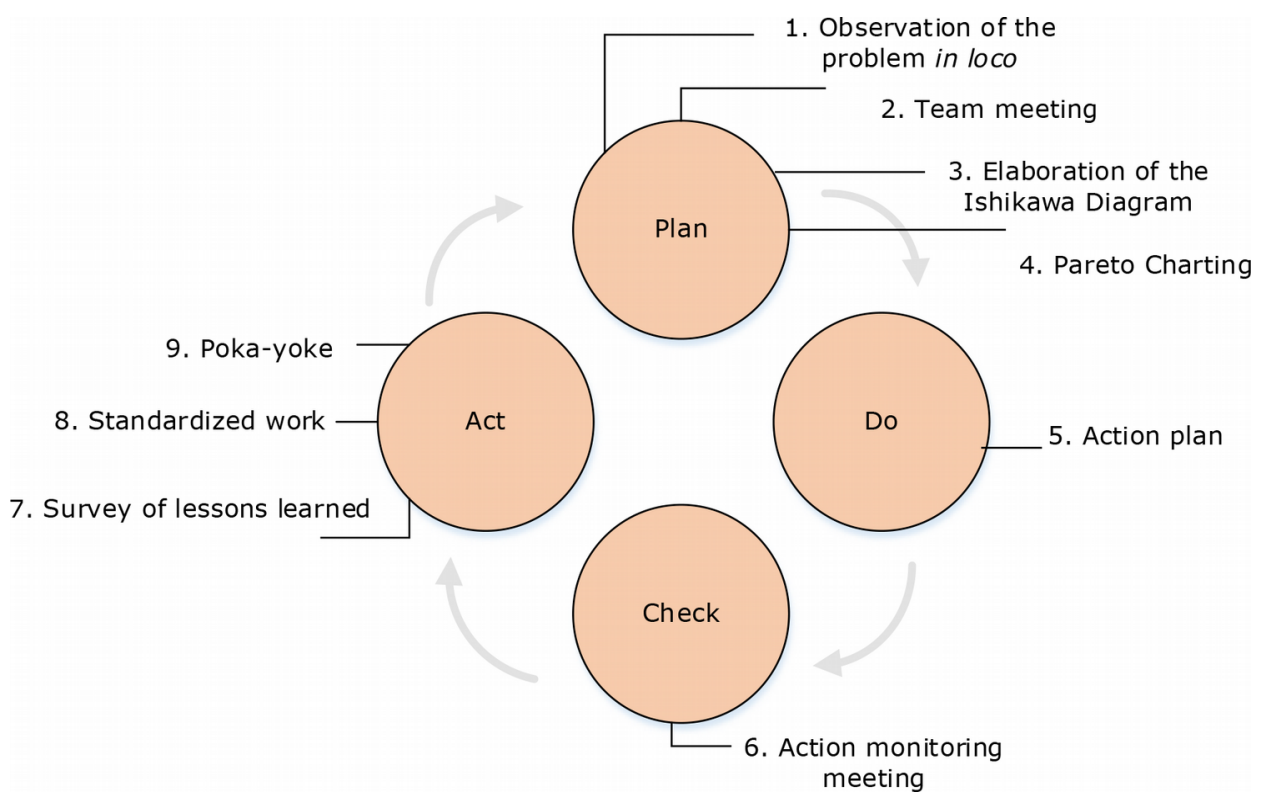

Figure 5. PDCA project management model Kaizen

Overall, all projects used Lean operational tools such as Kaizen, PDCA, Ishikawa Diagram, Poka-yoke, and Standardized Work.

\subsection{Reduction of Energy Consumption}

For project management, a PDCA (Plan, do, check, act) was elaborated to better understand the initial situation and later analysis.

Using the Ishikawa Diagram methodology, the causes are identified through the $6 \mathrm{M}$ 's, being machine, method, material, measurement, environment and labor. Secondary causes are shown in Figure 6. 


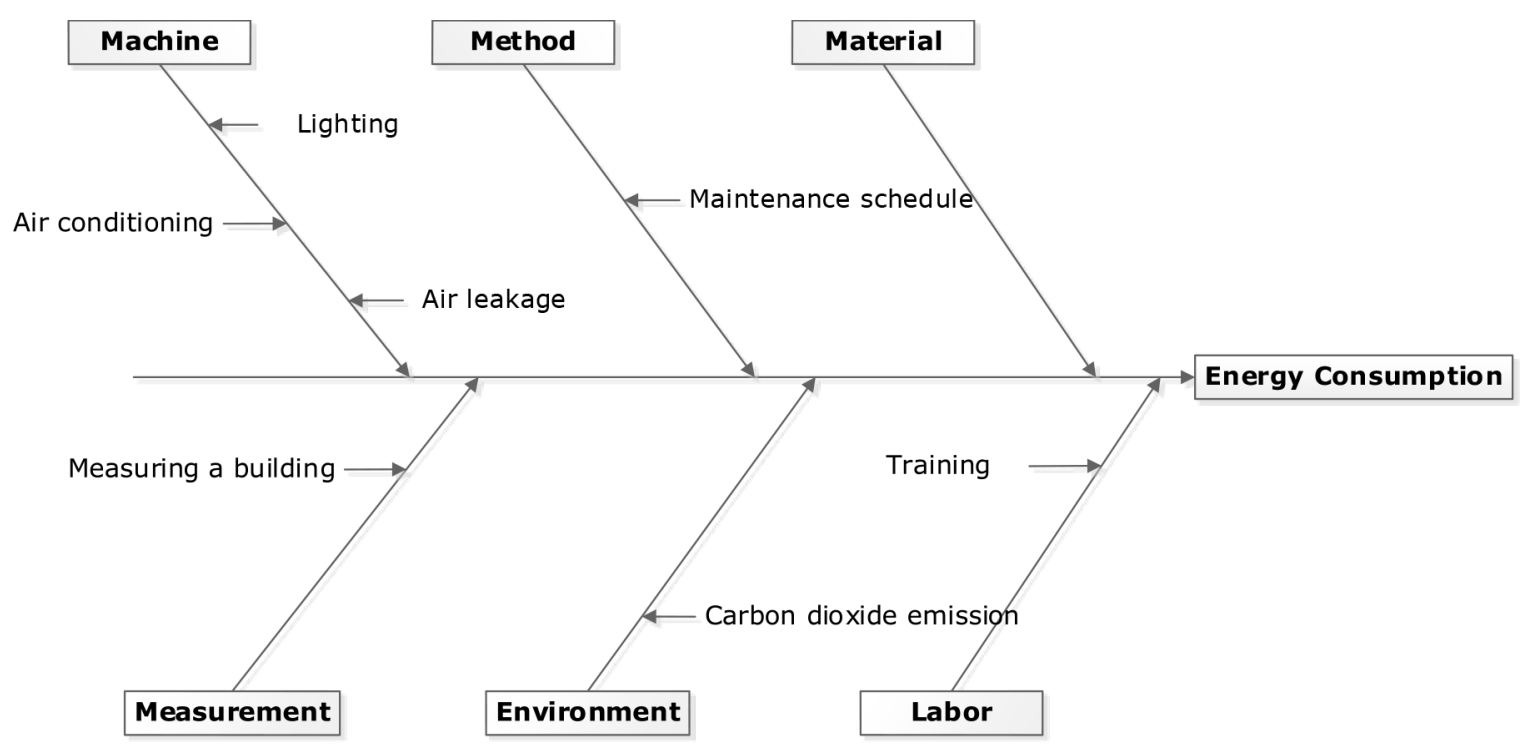

Figure 6. Ishikawa diagram for the reduction of energy consumption of Alpha

Subsequently, a Pareto Chart is drawn based on the data records to be analyzed, as shown in Figure 7. The unit of measure of the energy consumption items is Kilowatt hour.

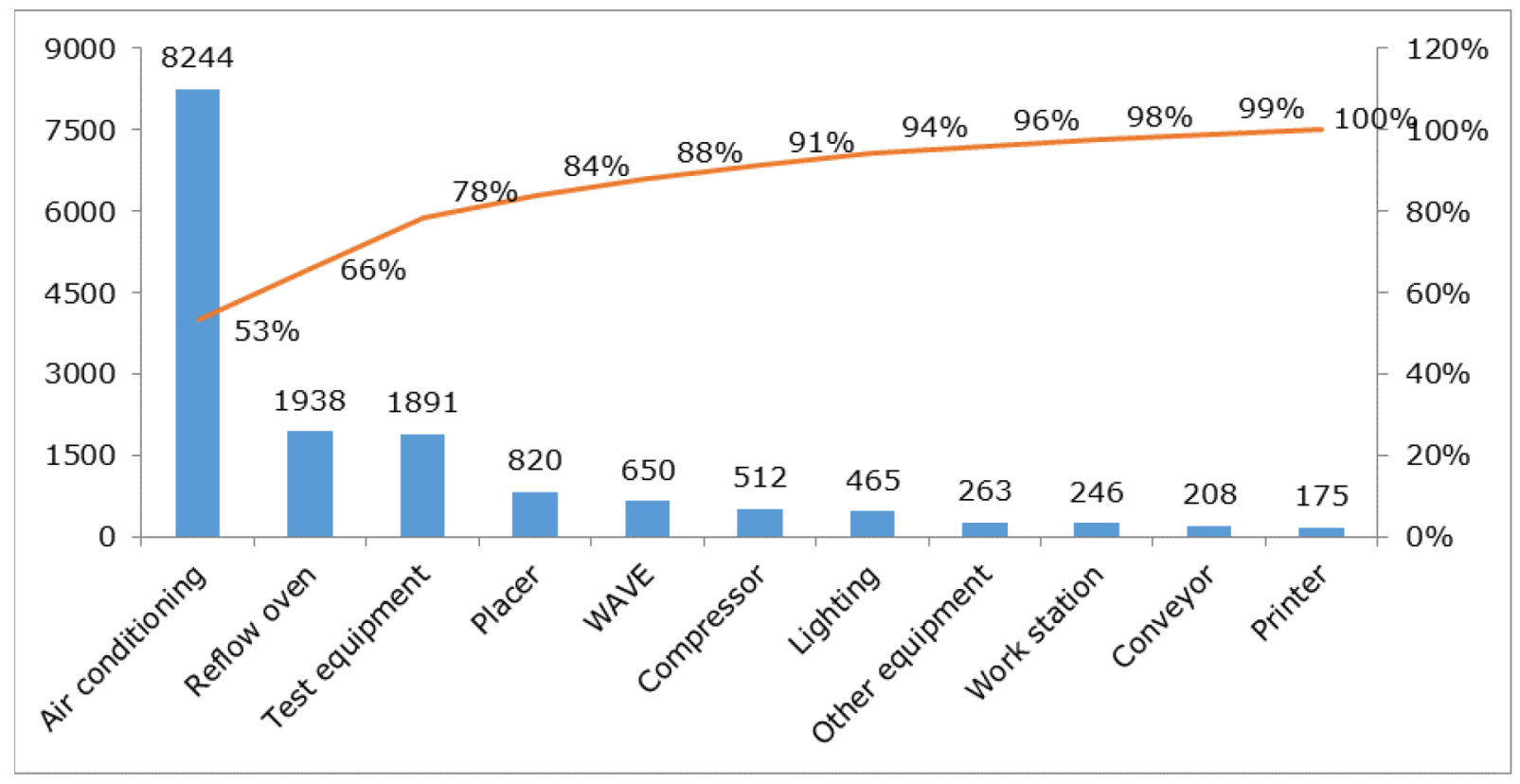

Figure 7. Pareto Chart for Alpha Power Consumption 
As shown in the chart, in a cross-sectional analysis of the Ishikawa Diagram, it is considered that the air conditioning, compressor, and lighting elements are the most impacting, accounting for $60 \%$ of the total energy use consumed.

For the reduction of the monthly energy consumption, three actions are drawn: the first one has as its goal the initial reduction of $2 \%$. Consequently, deriving in the second that is a reduction of the monthly cost and, finally, the implementation of good practices applied by other units to the problem.

There were 51 outbreaks of air leaks throughout the company and 100 more bulbs than needed. In this way, an action plan was prepared to solve the problems found to reduce energy consumption according to Table 4. The initial state quantitatively and the improvement objective is presented.

\begin{tabular}{|l|c|c|r|r|}
\hline \multicolumn{1}{|c|}{ Critical points } & Measure & Initial & Goal & Improvement \\
\hline Reduction of consumption of air conditioning & $\mathrm{kWh}$ & 11,057 & 8,769 & $21 \%$ \\
\hline Compressor consumption reduction & $\mathrm{kWh}$ & 12,306 & 10,706 & $13 \%$ \\
\hline Reduction of lamp consumption & $\mathrm{kWh}$ & 1,094 & 864.8 & $74 \%$ \\
\hline Reduction of lamps & Quantity/day & 51 & 0 & $12 \%$ \\
\hline Eliminate air leakage & Quantity/day & 0 & $100 \%$ \\
\hline Create preventive maintenance process & Unit & & $100 \%$ \\
\hline
\end{tabular}

Table 4. Plan to reduce the energy consumption of Alpha

The organization adopted software for detailed control of energy consumption. In some equipment Poka-Yokes were inserted for energy control, making it impossible to overuse.

As a result of this analysis, actions were established aiming at reducing air conditioning time and lessen the number of lamps, incorporated into the standardized work methods involved.

\subsection{Reduction of Water Consumption}

For the management of the project, a PDCA was elaborated for a better current understanding and later analysis. To observe the initial scenario of water consumption, monthly indicators were established for trend verification, visualized in Figure 8.

Water use was measured in cubic meters for the year 2014, with a total consumption of $6,710 \mathrm{~m}^{3}$ in January and $4,764 \mathrm{~m}^{3}$ in December. The goal is $0.63 \mathrm{~m}^{3}$ per person. The use of water by municipal supply 
is much higher than that used by artesian wells. Also, about the target, only in February 2014 was it possible to attend. But this is only a factor of comparison for what the company intends to achieve.

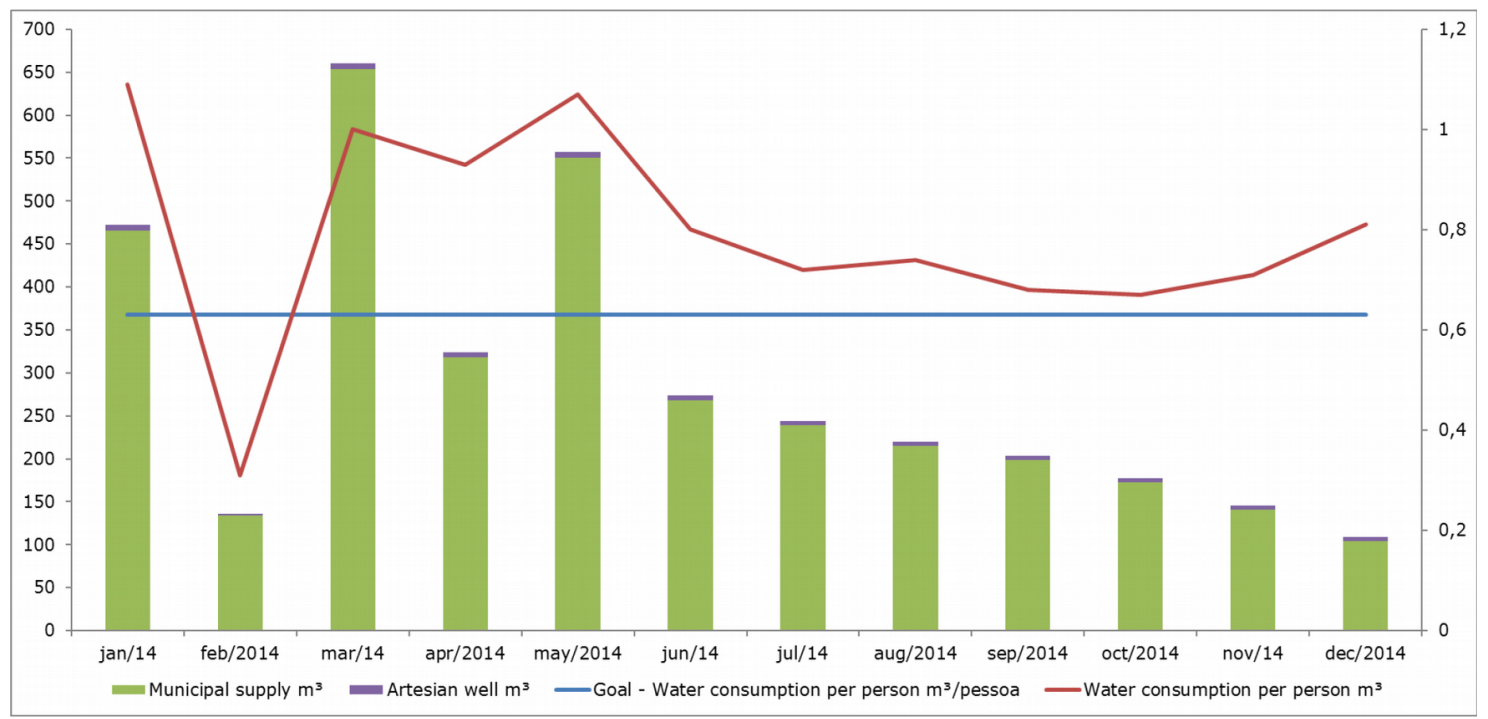

Figure 8. Monthly indicators for checking water consumption

Using the Ishikawa Diagram methodology, secondary causes are identified through primary causes identified in the diagram. These are shown in Figure 9.

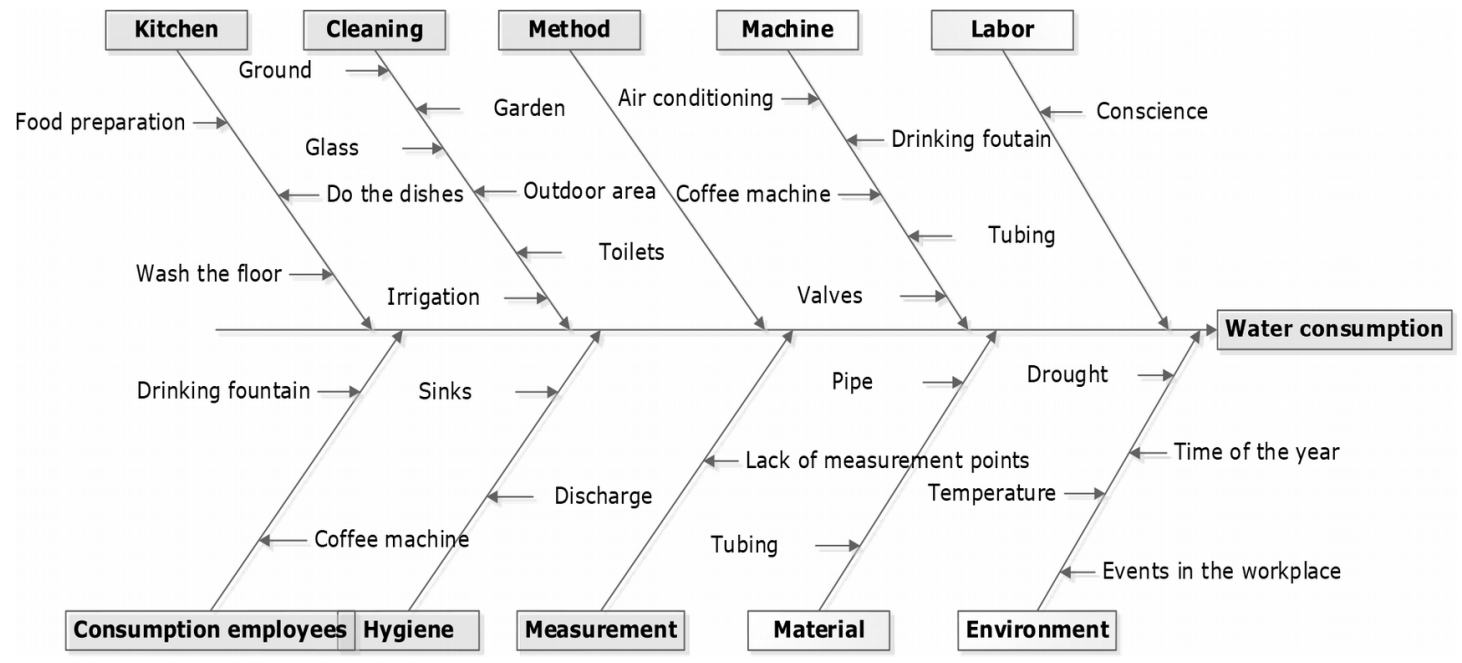

Figure 9. Ishikawa diagram for reducing water consumption by Alpha 
Subsequently, a Pareto Chart is drawn based on the data records to be analyzed, shown in Figure 10. The unit of measure of the items is liters.

The present situation shows the high consumption of water, being the average consumed of $0,83 \mathrm{~m}^{3}$ per person; Disposal of water from the air conditioning; Total use of artesian well or public treatment. The objectives for these will be an average water consumption of $0.63 \mathrm{~m}^{3}$ per person per month, a reduction of $17 \%$ about the average consumed; Reuse of rainwater; Reuse of air conditioning. Table 5 presents in detail the objectives to be achieved as a macro action plan.

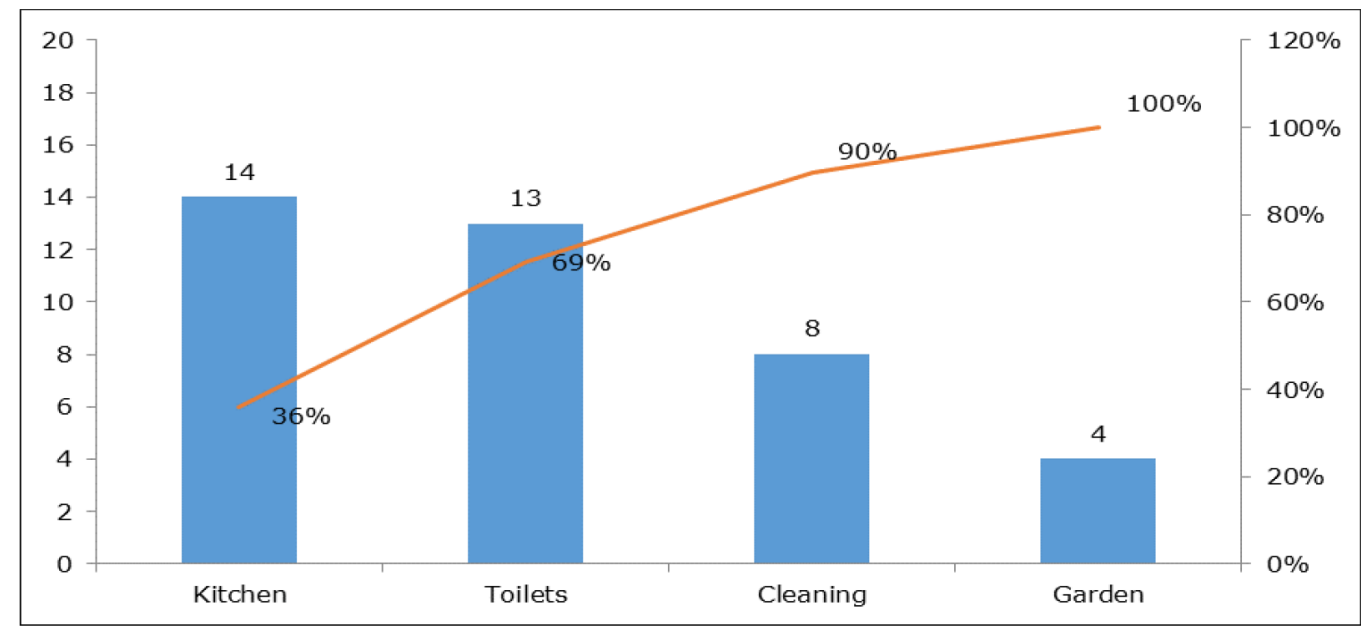

Figure 10. Pareto Chart for Alpha Water Consumption

\begin{tabular}{|l|c|r|r|r|}
\hline \multicolumn{1}{|c|}{ Critical points } & Measure & Initial & Goal & Improvement \\
\hline Reduction of water consumption & Liters/person & 0.83 & 0.69 & $21 \%$ \\
\hline Rainwater reuse & Liters & 0 & 0 & $100 \%$ \\
\hline Reuse of water from air conditioning & Liters & 0 & 0 & $100 \%$ \\
\hline
\end{tabular}

Table 5. Alpha water consumption reduction plan

After outlining the macro action plan, activities were also described to better reach the results.

Data were collected over a period of two weeks. Some of the critical points were healed faster others took little more time, mainly due to their solution complexity. The result is shown below in Table 6 in percent, representing the level of improvement in each aspect. 


\begin{tabular}{|l|r|}
\hline \multicolumn{1}{|c|}{ Aspects } & Improvement \\
\hline Reduction of water consumption per person & $22 \%$ \\
\hline Brushing teeth (two glasses per person) & $33 \%$ \\
\hline Wash hands (four times per person) & $17 \%$ \\
\hline Discharge in the toilet (four times per person) & $22 \%$ \\
\hline Adjust faucets, toilets and urinals & $100 \%$ \\
\hline Economy water air conditioning & $100 \%$ \\
\hline Reducing water leaks & $100 \%$ \\
\hline
\end{tabular}

Table 6. Level of improvement in aspects to reduce water consumption

In some places, such as toilets, taps, and urinals, Poka-yokes were implemented to minimize water use. These are controlled to eliminate the amount of water required for use.

The result had a positive impact on financial performance and reduced environmental impact on better water use. Also, the actions in Table 6 were inserted into the local standardized work.

\section{Conclusions and Discussions}

The company surveyed classifies the impact of financial gains into three levels, such as high, medium and low. High when any improvement results in the impact on the organization's profits and losses, with the highest level of financial impact being positive. Medium is the economic gains that do not even have an impact on operating profit. Low when you decrease the inventory level and reduce accounts payable and receivable.

The project that reduced energy consumption was classified as high, as it impacted profits and losses and water was average, obtaining gains not more in an account in the financial numbers. The water project was measured a monthly increase of 59,188 gallons of water per month or the equivalent of a semiOlympic pool.

Thus, through a case study, we conclude that:

1. In the case studied, the use of Lean operational practices contributed to achieve results of reduction of consumption and minimization of environmental impact;

2. Some Lean operating practices leverage environmental impact and reduce costs for the organization, such as Kaizen, PDCA, Ishikawa Diagram, Poka-Yoke, and Standardized Work. 
- Kaizen has systematized the use of various Lean operating practices, effectively achieving the achievement of the proposed objectives;

- The PDCA imposes cyclical management activities to determine greater positivity in achieving results, participating in all stages of the Kaizen events group. Used in planning the control and improvement of the process in search of the identification of the initial scenario and its gaps about the utilization of the natural resources;

- The Ishikawa Diagram contributes to greater visibility of the situation for solving environmental problems;

- Poka-Yoke reduces manufacturing of defective products, reduced consumption of resources such as materials and energy, reduction of inventory, reduction of products discarded in the environment;

- The Standardized Work in the workstations for better use of natural resources, avoiding excessive use of materials and additional operations. Standardized Work is updated with the lessons learned from the Kaizens;

3. Lean Manufacturing operational practices can result in cost savings. For the case studied, an annual cost reduction of US $\$ 17,900.00$ was recorded. The project to reduce energy consumption had its relative participation in the total of US $\$ 12,900.00$ and the project to reduce water consumption US $\$ 5,000.00$.

4. Lean operating practices can be complementary to environmental management practices. The company studied applies Lean tools intensively to reduce environmental impact.

This research was mainly limited to the single case study method, content analysis for collected data and the type of organizational environment. Future research is suggested to be compared with the results of this study, as with other methodological procedures. We present a review of the Lean literature and environmental aspects, the methods used in the research and a description of the case study followed by the analysis of Lean's operational practices for environmental improvements. 


\section{References}

American Society for Quality. Fishbone diagram. http://asq.org/learn-about-quality/cause-analysistools/overview/fishbone.html (Accessed: June).

Andriankaja, H., Vallet, F., Le Duigou, J., \& Eynard, B. (2015). A method to ecodesign structural parts in the transport sector based on product life cycle management. Journal of Cleaner Production, 94, 165-176. https://doi.org/10.1016/j.jclepro.2015.02.026

Araújo, M.G., Magrini, A., Mahler, C.F., \& Bilitewski, B. (2012). A model for estimation of potential generation of waste electrical and electronic equipment in Brazil. Waste Management, 32, 335-342. https://doi.org/10.1016/j.wasman.2011.09.020

Atkinson, R. (1994). New models of pollution prevention technical assistance. Journal of Cleaner Production, 2, 101-106. https://doi.org/10.1016/0959-6526(94)90007-8

Azevedo, S.G., Carvalho, H., Duarte, S., \& Cruz-Machado, V. (2012). Influence of green and lean upstream supply chain management practices on business sustainability. IEEE Transactions on Engineering Management, 59(4), 753-765. https://doi.org/10.1109/TEM.2012.2189108

Baldwin, J.S., Allen, P.M., Winder, B., \& Ridgway, K. (2005). Modelling manufacturing evolution: thoughts on sustainable industrial development. Journal of Cleaner Production, 13(9), 887-902.

https://doi.org/10.1016/j.jclepro.2004.04.009

Bandehnezhad, M., Zailani, S., \& Fernando, Y. (2012). An empirical study on the contribution of lean practices to environmental performance of the manufacturing firms in northern region of Malaysia. International Journal of Value Chain Management, 6(2), 144-168. https://doi.org/10.1504/IJVCM.2012.048379

Bardin, L. (1977). L'Analyse de contenu. Paris: Presses Universitaires de France.

Baumann, H., Boons, F., \& Bragd, A. (2002). Mapping the green product development field: engineering, policy and business perspectives. Journal of Cleaner Production, 10, 409-425. https://doi.org/10.1016/S09596526(02)00015-X

Belekoukias, I., Garza-Reyes, J.A., \& Kumar, V. (2014). The impact of lean methods and tools on the operational performance of manufacturing organisations. International Journal of Production Research, 52(18), 5346-5366. https://doi.org/10.1080/00207543.2014.903348

Bergmiller, G.G., \& McCright, P.R. (2009). Parallel models for lean and green operations; In Proceedings of the 2009 Industrial Engineering Research Conference. 
Black, J.T. (1998). The factory project with future (1. ed.). Porto Alegre: Bookman.

Bouzon, M., Govindan, K., \& Rodriguez, C.M.T. (2015). Reducing the extraction of minerals: reverse logistics in the machinery manufacturing industry sector in Brazil using ISM approach. Resources Policy, 46, 27-36. https://doi.org/10.1016/j.resourpol.2015.02.001

Browning, T.R., \& Heath, R.D. (2009). Reconceptualizing the effects of lean on production costs with evidence from the F-22 program. Journal of Operations Management, 27(1), 23-44.

https://doi.org/10.1016/j.jom.2008.03.009

Cagno, E., Trucco, P., \& Tardini, L. (2005). Cleaner production and profitability: analysis of 134 industrial pollution prevention (P2) project reports. Journal of Cleaner Production, 13, 593-605.

https://doi.org/10.1016/j.jclepro.2003.12.025

Campos, L.M.S., \& Vazquez-Brust, D.A. (2016). Lean and green synergies in supply chain management. Supply Chain Management: An International Journal, 21(5), 627-641. https://doi.org/10.1108/SCM-03-2016-0101

Carvalho, H., Azevedo, S.G., \& Cruz-Machado, V. (2010). Supply chain performance management: lean and green paradigms. International Journal Business Performance and Supply Chain Modelling, 2(3/4), 304-333. https://doi.org/10.1504/IJBPSCM.2010.036204

Carvalho, H., Duarte, S., \& Cruz-Machado, V. (2011). Lean, agile, resilient and green: divergencies and synergies. International Journal of Lean Six Sigma, 2(2), 151-179. https://doi.org/10.1108/20401461111135037

Chan, J.K.Y., \& Wong, M.H. (2013). A review of environmental fate, body burdens, and human health risk assessment of PCDD/Fs at two typical electronic waste recycling sites in China. Science of the Total Environment, 463/464, 1111-1123. https://doi.org/10.1016/j.scitotenv.2012.07.098

Chandrakumar, C., Gowrynathan, J., Kulatunga, A.K., \& Sanjeevan, N. (2016). Incorporate LEAN and Green Concepts to Enhance the Productivity of Transshipment Terminal Operations. Procedia CIRP, 40, 301-306. https://doi.org/10.1016/j.procir.2016.01.042

Chiang, T.A., \& Roy, R. (2012). An intelligent benchmark-based design for environment system for derivative eletronic product development. Computers in Industry, 63, 913-929.

https://doi.org/10.1016/j.compind.2012.08.014

Chiarini, A. (2014). Sustainable manufacturing-greening processes using specific Lean Production tools: an empirical observation from European motorcycle component manufacturers. Journal of Cleaner Production, 85, 226-233. https://doi.org/10.1016/j.jclepro.2014.07.080 
Dangelico, R.M., \& Pontrandolfo, P. (2010). From green product definitions and classifications to the Green Option Matrix. Journal of Cleaner Production, 18(16/17), 1608-1628.

https://doi.org/10.1016/j.jclepro.2010.07.007

Dhingra, R., Das, S., \& Kress, R. (2012). Making progress towards more sustainable societies through lean and green initiatives. Journal of Cleaner Production, 37, 400-402. https://doi.org/10.1016/j.jclepro.2012.06.014

Dhingra, R., Kress, R., \& Upreti, G. (2014). Does lean mean green? Journal of Cleaner Production, 85, 1-7. https://doi.org/10.1016/j.jclepro.2014.10.032

Dües, C.M., Tan, K.H., \& Lim, M. (2013). Green as the new lean: how to use lean practices as a catalyst to greening your supply chain. Journal of Cleaner Production, 40, 93-100.

https://doi.org/10.1016/j.jclepro.2011.12.023

Eisenhardt, K. (1989). Building Theories from Case Study Research. The Academy of Management Review, 14(4), 532-550.

Espadinha-Cruz, P., Grilo, A., Puga-Leal, R., \& Cruz-Machado, V. (2011). A model for evaluating lean, agile, resilient and green practices interoperability in supply chains. Proceedings of 2011 IEEE International Conference on Industrial Engineering and Engineering Management. Singapore, 1209-1213. https://doi.org/10.1109/IEEM.2011.6118107

EPA - United States Environmental Protection Agency (2006). The Lean and Environment Toolkit. United States.

Ericsson (2012). Ericsson Mobility Report: On the pulse of the networked society 2012. http://www.ericsson.com/res/docs/2012/ericsson-mobility-report-november-2012.pdf (Accessed: May).

Faulkner, W., \& Badurdeen, F. (2014). Sustainable Value Stream Mapping (Sus-VSM): Methodology to Visualize and Assess Manufacturing Sustainability Performance. Journal of Cleaner Production, 85, 8-18. https://doi.org/10.1016/j.jclepro.2014.05.042

Fercoq, A., Lamouri, S., \& Carbone, V. (2016). Lean/Green integration focused on waste reduction techniques. Journal of Cleaner Production, 137, 567-578. https://doi.org/10.1016/j.jclepro.2016.07.107

Fiksel, J. (2009). Design for Environment: A Guide to Sustainable Product Development (2. ed.). New York: McGraw Hill.

Florida, R. (1996). Lean and green: the move to environmentally conscious manufacturing. California Management Review, 39(1), 80-105. https://doi.org/10.2307/41165877 
Freitas, H.M.R., Cunha Jr., M.V.M., \& Moscarola, J. (1997). Application of software systems to aid in the analysis of content. USP Management Review, 32(3), 97-109.

Galeazzo, A., Furlan, A., \& Vinelli, A. (2014). Lean and green in action: interdependencies and performance of pollution prevention projects. Journal of Cleaner Production, 85, 191-200.

https://doi.org/10.1016/j.jclepro.2013.10.015

Garza-Reyes, J.A. (2015). Lean and green - a systematic review of the state of the art literature. Journal of Cleaner Production, 102, 18-29. https://doi.org/10.1016/j.jclepro.2015.04.064

Garza-Reyes, J.A., Winck-Jacques, G., Lim, M.K., Kumar, V., \& Rocha-Lona, L. (2014). Lean and green e synergies, differences, limitations, and the need for Six Sigma. In: Advances in Production Management Systems. Innovative and Knowledgebased Production Management in a Global-local World. IFIP Advances in Information and Communication Technology, 439, 71-81. https://doi.org/10.1007/978-3-662-44736-9_9

Godoy, A.S. (1995). Qualitative Research: Fundamental Types. Business Administration Magazines, 35(3), 20-29.

Govindan, K., Azevedo, S.G., Carvalho, H., \& Cruz-Machado, V. (2015). Lean, green and resilient practices influence on supply chain performance: interpretive structural modelling approach. International Journal of Environmental Science Technology, 12(1), 15-34. https://doi.org/10.1007/s13762-013-0409-7

Hajmohammad, S., Vachon, S., Klassen, R.D., \& Gavronski, I. (2013). Lean management and supply management: their role in green practices and performance. Journal of Cleaner Production, 39(1), 312-320. https://doi.org/10.1016/j.jclepro.2012.07.028

Hooley, G., Piercy, N.F., \& Nicoulaud, B. (2011). Marketing Strategy and Competitive Positioning (4. ed.). São Paulo: Pearson Prentice Hall.

Houe, R., \& Grabot, B. (2009). Assessing the compliance of a product with an eco- label: from standards to constraints. International Journal of Production Economics, 121, 21-38.

https://doi.org/10.1016/j.ijpe.2008.03.014

Hüttmeir, A., Treville, S., Ackere, A.V., Monnier, L., \& Prenninger, J. (2009). Trading off between heijunka and Just-in-sequence. International Journal of Production Economics, 118(2), 501-507. https://doi.org/10.1016/j.ijpe.2008.12.014

Imai, M. (1986). Kaizen: The Key to Japan's Competitive Success. New York: Random House.

Ishikawa, K., \& Loftus, J.H. (1990). Introduction to quality control. Tokyo Japan: 3A Corporation. 
Jabbour, A.B.L.S., Jabbour, C.J.C., Freitas, W.R.S., \& Teixeira, A.A. (2013). Lean and green? Empirical evidence from the Brazilian automotive industry. Gestão \& Produção, 20(3), 653-665.

https://doi.org/10.1590/S0104-530X2013000300011

Johansson, G., \& Sundin, E. (2014). Lean and green product development: two sides of the same coin? Journal of Cleaner Production, 85, 104-121. https://doi.org/10.1016/j.jclepro.2014.04.005

King, A.A., \& Lenox, M.J. (2001). Lean and Green? An Empirical Examination of the Relationship Between Lean Production and Environmental Performance. Production and Operations Management. 10(3), 225-358. https://doi.org/10.1111/j.1937-5956.2001.tb00373.x

Kishida, M., Silva, A., \& Guerra, E. (2006). Benefits of Deploying Standardized Work at Thyssenkrupp. Lean Institute Brazil.

Kleindorfer, P.R., Singhal, K., \& Van Wassenhove, L.N. (2005). Sustainable operations management. Production and Operations Management, 14(4), 482-492. https://doi.org/10.1111/j.1937-5956.2005.tb00235.x

Kobayashi, K. (2005). What is 5S? A Content Analysis of Japanese Management Approach. Unpublished Master's Thesis, Griffith University, Southport.

Larson, T., \& Greenwood, R. (2004). Perfect complements: synergies between lean production and eco-sustainability initiatives. Environmental Quality Management, 13(4), 27-36. https://doi.org/10.1002/tqem.20013

Li, S., Rao, S.S., Ragu-Nathan, T.S., \& Ragu-Nathan, B. (2005). Development and validation of a measurement instrument for studying supply chain management practices. Journal of Operations Management, 23(6), 618-641. https://doi.org/10.1016/j.jom.2005.01.002

Martinez, F., Vazquez-Brust, D.A., Peattie, K., \& Zokaei, K. (2012). Achieving greener growth: a business perspective for proactive commitment (Chapter 10). In Vazquez-Brust, D.A. \& Sarkis, J. (Eds.). Green Growth: Managing the Transition to a Sustainable Economy. Greening of Industry Networks Studies. Springer, Netherlands. https://doi.org/10.1007/978-94-007-4417-2_10

Martins, G.A. (2008). Case study: a reflection on applicability in research in Brazil. Journal of Accounting and Organizations, 2(2), 9-18.

Matos, S., \& Hall, J. (2007). Integrating sustainable development in the supply chain: the case of sustainable development in the oil and gas and agricultural biotechnology. Journal of Operations Management, 25(6), 1083-1102. https://doi.org/10.1016/j.jom.2007.01.013 
Maxwell, J., Briscoe, F., Schenk, B., \& Rothenberg, S. (1998). Case study: Honda of America Manufacturing, Inc: can lean production practices increase environmental performance? Environmental Quality Management, 8 (1), 53-61. https://doi.org/10.1002/tqem.3310080107

McLachlin, R. (1997). Management initiatives and just-in-time manufacturing. Journal of Operations Management, 15(4), 271-292. https://doi.org/10.1016/S0272-6963(97)00010-7

Miettinem, P., \& Hamalainen, R.P. (1997). How to benefit from decision analysis in environmental life cycle assessment (LCA). European Journal of of Operational Research, 102(2), 279-294. https://doi.org/10.1016/S0377-2217(97)00109-4

Miller, G., Pawloski, J., \& Standridge, C.R. (2010). A case of lean, sustainable manufacturing. Journal of Industrial Engineering and Management, 3(1), 11-32.

Mollenkopf, D., Stolze, H., Tate, W.L., \& Ueltschy, M. (2010). Green, lean, and global supply chain. International Journal of Physical Distribution \& Logistics Management, 40(1/2), 14-41. https://doi.org/10.1108/09600031011018028

Montabon, F., Sroufe, R., \& Narasimhan, R. (2007). An examination of corporate reporting, environmental management practices and firm performance. Journal of Operations Management, 25(5), 998-1014. https://doi.org/10.1016/j.jom.2006.10.003

Nakajima, S. (1988). Total Productive Maintenance. Cambridge: Productivity Press.

Ohno, T. (1997). The Toyota Production System. Porto Alegre: Artes Médicas.

Orlins, S., \& Guan, D. (2015). China's toxic informal e-waste recycling: local approaches to a global environmental problem. Journal of Cleaner Production, 114, 71-80. https://doi.org/10.1016/j.jclepro.2015.05.090

Pampanelli, A.B., Found, P., \& Bernardes, A.M. (2014). A Lean \& Green Model for a production cell. Journal of Cleaner Production, 85, 19-30. https://doi.org/10.1016/j.jclepro.2013.06.014

Parveen, C.M., Kumar, A.R.P., \& Narasimha-Rao, T.V.V.L. (2011). Integration of lean and green supply chain: impact on manufacturing firms in improving environmental efficiencies. Proceedings of International Conference on Green Technology and Environmental Conservation (GTEC), Chennai, 143-147. https://doi.org/10.1109/GTEC.2011.6167659

Paumgartten, P.V. (2003). The business case for high-performance green buildings: sustainability and its financial impact. Journal of Facilities Management, 2(1), 26-34. https://doi.org/10.1108/14725960410808096 
Piercy, N., \& Rich, N. (2015). The relationship between lean operations and sustainable operations. International Journal of Operations \& Production Management, 35(2), 282-315. https://doi.org/10.1108/IJOPM-032014-0143

Pojasek, R.B. (2008). Quality toolbox: framing your lean-to-green effort. Environmental Quality Management, 18(1), 85-93. https://doi.org/10.1002/tqem.20198

Pusavec, F., Krajnik, P., \& Kopav, J. (2010). Transitioning to Sustainable Production-Part I: Application on Machining Technologies. Journal of Cleaner Production, 18(2), 174-184.

https://doi.org/10.1016/j.jclepro.2009.08.010

Ritzman, L.P., \& Krajewski, L.J. (2004). Production management and operations. São Paulo: Pearson Prentice Hall.

Rother, M., \& Shook, J. (2003). Learning to View: mapping the value stream to add value and eliminate waste. São Paulo: Lean Institute Brazil.

Sagnak, M., \& Kazancoglu, Y. (2016). Integration of green lean approach with six sigma: an application for flue gas emissions. Journal of Cleaner Production, 127, 112-118. https://doi.org/10.1016/j.jclepro.2016.04.016

Salleh, N.A.M., Kasolang, S., \& Jaffar, A. (2012). Green Lean Total Quality Information Management in Malaysian Automotive Companies. Procedia Engineering, 41, 1708-1713. https://doi.org/10.1016/j.proeng.2012.07.372

Santos, R.F., \& Marins, F.A.S. (2015). Integrated model for reverse logistics management of electronic products and components. Procedia Computer Science, 55, 575-585. https://doi.org/10.1016/j.procs.2015.07.047

Sarkis, J. (2003). A strategic decision making framework for green supply chain management. Journal of Cleaner Production, 11(4), 397-409. https://doi.org/10.1016/S0959-6526(02)00062-8

Shah, R., \& Ward, P.T. (2003). Lean Manufacturing: context, practice bundles, and performance. Journal of Operations Management, 21(2), 129-149. https://doi.org/10.1016/S0272-6963(02)00108-0

Shah, R., \& Ward, P.T. (2007). Defining and developing measures of lean production. Journal of Operations Management, 25(4), 785-805. https://doi.org/10.1016/j.jom.2007.01.019

Shingo, S. (1988). Zero quality control: source inspection and the poka-yoke system. Productivity Press.

Shingo, S. (1996). The Toyota Production System. Porto Alegre: Artes Médicas.

Simpson, D.F., \& Power, D.J. (2005). Use the supply relationship to develop lean and green suppliers. Supply Chain Management: An International Journal, 10(1), 60-68. https://doi.org/10.1108/13598540510578388 
Sroufe, R. (2003). Effect of environmental management systems on environmental management practices and operations. Production and Operations Management Journal, 12(3), 416-431. https://doi.org/10.1111/j.19375956.2003.tb00212.x

Swanson, L. (2001). Linking maintenance strategies to performance. International Journal of Production Economics, 70(3), 237-244. https://doi.org/10.1016/S0925-5273(00)00067-0

Thanki, S., Govindan, K., \& Thakkar, J. (2016). An investigation on lean-green implementation practices in Indian SMEs using analytical hierarchy process (AHP) approach. Journal of Cleaner Production, 135, 284-298. https://doi.org/10.1016/j.jclepro.2016.06.105

Ugarte, G.M., Golden, J.S., \& Dooley, K.J. (2016). Lean versus green: The impact of lean logistics on greenhouse gas emissions in consumer goods supply chains. Journal of Purchasing and Supply Management, 22(2), 98-109. https://doi.org/10.1016/j.pursup.2015.09.002

Verrier, B., Rose, B., \& Caillaud, E. (2016). Lean and Green strategy: the Lean and Green House and maturity deployment model. Journal of Cleaner Production, 116, 150-156.

https://doi.org/10.1016/j.jclepro.2015.12.022

Voss, C., Tsikriktsis, N., \& Frohlich, M. (2002). Case research in operations management. International Journal of Operations \& Production Management, 22(2), 195-219. https://doi.org/10.1108/01443570210414329

Whithmore, T. (2008). Standardized Work: document your process and make problems visible. Manufacturing Engineering, 140(5).

Wiengarten, F., Fynes, B., \& Onofrei, G. (2013). Exploring synergetic effects between investments in environmental and quality/lean practices in supply chains. Supply Chain Management: An International Journal, 18(2), 148-160. https://doi.org/10.1108/13598541311318791

Womack, J.P., \& Jones, D.T. (1998). The Lean Thinking in Business (4 ed.). Rio de Janeiro: Campus.

Womack, J.P., Jones, D.T., \& Roos, D. (1990). The machine that changed the world. New York: Macmillan.

Yang, M.G., Hong, P., \& Modi, S.B. (2011). Impact of lean manufacturing and environmental management on business performance: an empirical study of manufacturing firms. International Journal of Production Economics, 128(2), 251-261. https://doi.org/10.1016/j.ijpe.2010.10.017

Yin, R.K. (2001). Case Study: Planning and Methods (2 ed.). Porto Alegre: Bookman.

Yin, R.K. (2010). Case Study: Planning and Methods (4 ed.). Porto Alegre: Bookman. 
Zhang, L., Zhan, Y., Liu, Z.F., Zhang, H.C., \& Li, B.B. (2011). Development and analysis of design for environment oriented design parameters. Journal of Cleaner Production, 19(15), 1723-1733. https://doi.org/10.1016/j.jclepro.2011.06.012

Zhao, X., Huo, B., Flynn, B., \& Yeung, J. (2008). The impact of power relationship commitment on the integration between manufacturers and customers in a supply chain. Journal of Operations Management, 26(3), 368-388. https://doi.org/10.1016/j.jom.2007.08.002

Zokaei, K., Lovins, H., Wood, A., \& Hines, P. (2013). Creating a Lean and Green Business System: Techniques for Improving Profits and Sustainability. CRC Press, Taylor \& Francis Group, Boca Raton, FL. https://doi.org/10.1201/b14874

Zwetsloot, G. (1995). Improving cleaner production by integration into the management of quality, environment and working conditions. Journal of Cleaner Production, 3, 61-66. https://doi.org/10.1016/09596526(95)00046-H

\section{Appendix A}

\section{Research Protocol}

This Research Protocol describes the procedures for better follow-up of the research before the methodological procedures and work planning for the case studies.

\section{Scope of Paper}

The industry that needs to be researched is the production of electronic products.

\section{Context of Research}

How can environmental improvements be achieved through Lean Manufacturing operational practices?

\section{Study Objects}

The objects of study are operational practices of Lean Manufacturing and its results generated, mainly on the environment, in the electronics industry. 


\section{Profile of Respondents}

The interviewees were participants in the Lean and environment areas of the company, two Lean coordinators and for the environment an administrative assistant and an environmental expert. Many companies call this sector of Lean as continuous improvement or Kaizen sector. The Lean department is under the leadership of the industrial manager, but has no dependency link. It is independent and has autonomy to carry out its work. The environment sector also performs functions related to the health and safety of the people who work in the company, as well as disseminating the concepts sent by the customer to production in product design.

With these participants or guides within the company were jointly defined the following questions for the visits:

- The time for visits in the company around three to four hours;

- The frequency of the visits being weekly, one in each researched sector;

- For the occurrence of the visits, the prior appointment for the reception of the need for equipment for individual safety when the visit is applicable.

\section{Execution of a Pilot Test}

An initial pilot test was performed to verify the compliance of this research protocol. The criteria defined in item 4 of this protocol was identified from the pilot test making it effective for the study of the case.

\section{Contact Preparation and Initial Visit}

Initially, a mapping of possible electronics manufacturing companies is carried out. Among these three are chosen to compose the number of cases to be studied. The choice is at the discretion of the researcher, being criteria the size of the company, form of work (previously researched to understand a little of the company) and location. Subsequently, the contact should be done by telephone, as it is clearer to present the company the project and the faster the response to carry out the work.

Once accepted or authorized to enter the company, an initial meeting to present the project of the work is necessary to release the professional's participation. At the meeting, also make clear the frequency of visits not to lose contact and also a frequently defined continuity of the research. This frequency must be at least one to two days per week. 


\section{Data Collect}

To collect the data, a semi-structured script with open-ended questions will be elaborated, since through the observations and dialogues between interviewer and interviewee there may appear items or actions that were not in context and may be useful. This semi-structured script can be seen in APPENDIX B. The questions of the script were elaborated through the bibliographic review and objectives of this research.

\section{Data Analysis}

The data will be evaluated and analyzed by the content analysis technique. The data will be transcribed in a dissertation with greater intention of the elaboration of tables and figures for better understanding and presentation of the case with the data collected.

\section{Elaboration of the Report}

So that no information is lost throughout the research, once the researcher or interviewer leaves the company the report should already be written. One concern is not forgetting any information and another that everything is clearer at the moment you are working in loco. If you leave the risk of forgetting some important information, it is greater.

\section{Appendix B}

\section{Semi-Structured Script}

This semi-structured script describes the questions elaborated to study the case studied, assisting as a guide. Since there are two departments involved with a lot of emphases, Lean Manufacturing and the Environment, some issues are directed specifically to one of these. This specification, when necessary, is pointed out in front of the question and is used for content analysis

1. How many employees work in the company?

2. What are the products manufactured by the company?

3. Does the company self-declare be Lean or does it have internal characteristics by a philosophical Lean production?

4. How is the Lean philosophy within the company?

5. Does the company in your process have any waste that impacts the environment? 
6. What is the flow of solid waste in the company?

7. What operations in production are the waste?

8. How is the final disposal of solid waste?

9. Is there a Lean tool that is not used but could be used for environmental improvement? (Lean and Environment)

10. Is there senior management support for using Lean practices in the company? (Lean)

11. Is there top management support for using environmental practices in the company? (Environment)

12. How does the environment department view the Lean in your routine? (Environment)

13. How does the Lean department visualize environmental management in its routine? (Lean)

14. Is there any difficulty in the relationship between the company's Lean system and the practices it uses? (Lean and Environment)

\section{Appendix C}

\section{Content Analysis}

\begin{tabular}{|c|c|c|c|}
\hline \multicolumn{4}{|c|}{ Category: Environmental Practices and Lean Operational Practices (Gap) } \\
\hline Subcategory & Questions & Verbalizations & Result / Output \\
\hline $\begin{array}{l}\text { Lean tool not } \\
\text { used for } \\
\text { environment }\end{array}$ & 9 & $\begin{array}{l}\text { Interviewee A: I believe that VSM was created to understand the } \\
\text { flow of value, but I do believe, and I have seen sketches of staff } \\
\text { trying to put the VSM to analyze the environmental issue of both } \\
\text { electricity consumption, water consumption and generation } \\
\text { waste. So I think VSM can rather be adapted to an environmental } \\
\text { view of processes. I'm remembering the VSM here. Perhaps, } \\
\text { from the moment you have an existing problem, any problem } \\
\text { analysis tool such as PDCA, such as } 5 \text { Whys, can also be used for } \\
\text { you to reach root cause and work on root cause... Maybe today } \\
\text { We have the Golf Score that analyzes ergonomic issues of the } \\
\text { operation ... Today we could put safety signs of work, ergonomic } \\
\text { issues in the Standardized Work, in that Standardized Work layout } \\
\text { that we put in, they could be putting environmental symbols. } \\
\text { Interviewee B: I think at first there are certainly tools that are } \\
\text { not used today that can be used. It all depends on the level of } \\
\text { analysis that we are. } \\
\text { Interviewee C: I think it would be enough to use the ones you } \\
\text { have for the environment. The PDCA is used a lot, we already } \\
\text { have this practice. } \\
\text { Interviewee D: Yes, because Lean has several tools. For example, } \\
\text { today I see one way, if not applied, in the future will be in the } \\
\text { development of another product. }\end{array}$ & $\begin{array}{l}\text { * Environmental VSM; } \\
\text { * PDCA for } \\
\text { environmental } \\
\text { solutions; } \\
\text { * Standard work for } \\
\text { resource use; } \\
\text { * Golf score for } \\
\text { ergonomics. }\end{array}$ \\
\hline
\end{tabular}




\begin{tabular}{|c|c|c|c|}
\hline \multicolumn{4}{|c|}{ Category: Use of environmental practices } \\
\hline Subcategory & Questions & Verbalizations & Result / Output \\
\hline $\begin{array}{l}\text { Administration } \\
\text { support }\end{array}$ & 10 e 11 & $\begin{array}{l}\text { Interviewee A: Yes, there is a lot of support. The plant manager, } \\
\text { in fact if we think of corporation, Alpha as a multinational since } \\
\text { the CEO there is such support. } \\
\text { Interviewee B: Yes. We could not have the structure we have } \\
\text { today, for example, all the coordinators, to have our area, to get } \\
\text { the attention of the staff to be able to do a project, to improve, if } \\
\text { they did not have the interest and the Support from top } \\
\text { management. } \\
\text { Interviewee C: Yes, it has management support. } \\
\text { Interviewee D: Yes, there is, support. }\end{array}$ & $\begin{array}{l}\text { There is management } \\
\text { support for Lean } \\
\text { Manufacturing and use } \\
\text { of environmental } \\
\text { practices }\end{array}$ \\
\hline Importance & 12 e 13 & $\begin{array}{l}\text { Interviewee A: And today in these materials, just as I mentioned } \\
\text { the tools, these materials do not have some details that contribute } \\
\text { a lot to the environment, they are not specific to the environment. } \\
\text { You have the opportunity to improve these materials, I would say } \\
\text { you have the opportunity, but I would say that thinking of cost } \\
\text { reduction has a number of initiatives. For example, reduction of } \\
\text { electricity, reduction of water consumption, they also reduce the } \\
\text { cost, which is what we seek in all Kaizens, and go against the } \\
\text { environment, meet the environmental need. It is not explicitly a } \\
\text { consequence of all our initiatives. } \\
\text { Interviewee B: We end up seeing some sort of daily question } \\
\text { like waste, or recycling, or some kind of these processes. So when } \\
\text { we are involved with any of these projects, yes, it is everyday. } \\
\text { Interviewee C: How I show the importance of environmental } \\
\text { work is through Lean. I need contact, that the environment sector } \\
\text { appears and to achieve this is through Lean. You do not have a } \\
\text { Kaizen just for production, but for top management. } \\
\text { Interviewee D: We already think about Lean today. It's natural } \\
\text { today. }\end{array}$ & $\begin{array}{l}\text { * Lean projects for } \\
\text { environmental } \\
\text { improvement; } \\
\text { * Relationship between } \\
\text { Lean and } \\
\text { environmental } \\
\text { practices. }\end{array}$ \\
\hline Difficulties & 14 & $\begin{array}{l}\text { Interviewee A: I do not think there is any limitation or barrier. I } \\
\text { think these barriers do not exist if we look at the point of view } \\
\text { that every process is a process that can be improved, can be } \\
\text { improved through the concepts of Lean, Lean tools. } \\
\text { Interviewee B: At first I do not see any technical difficulties } \\
\text { between the two. } \\
\text { Interviewee C: I think not, because for example, sometimes they } \\
\text { come up with some ideas that can not be implemented, but then } \\
\text { we explain and they understand. Then there is no difficulty. } \\
\text { Sometimes technical knowledge, where they sometimes give ideas, } \\
\text { but do not know the technical part of the environment area. } \\
\text { Interviewee D: No. Not anymore because it is already } \\
\text { widespread. Today practice is welcome. }\end{array}$ & $\begin{array}{l}\text { There is no limitation } \\
\text { or barrier between Lean } \\
\text { Manufacturing and } \\
\text { environmental } \\
\text { practices. }\end{array}$ \\
\hline
\end{tabular}

Journal of Industrial Engineering and Management, 2017 (www.jiem.org)

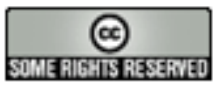

Article's contents are provided on an Attribution-Non Commercial 3.0 Creative commons license. Readers are allowed to copy, distribute and communicate article's contents, provided the author's and Journal of Industrial Engineering and Management's names are included. It must not be used for commercial purposes. To see the complete license contents, please visit http://creativecommons.org/licenses/by-nc/3.0/. 